\title{
Impact Testing on Composite Panels of Fiberglass, Carbon and Kevlar-Carbon
}

\author{
A comparison and validation study
}

\author{
EMILIAN IONUT CROITORU1*, GHEORGHE OANCEA ${ }^{1}$, NICOLAE CONSTANTIN² \\ ${ }^{1}$ Transilvania University of Brasov, Department of Manufacturing Engineering, 29 Eroilor Blvd., 500036, Brasov, Romania \\ ${ }^{2}$ Politehnica University of Bucharest, Department of Strength of Materials, 313 Splaiul Independentei, 060042, Bucharest, Romania
}

\begin{abstract}
A validation study between finite element analysis and experimental testing considering an impact loading of Fiberglass, Carbon and Kevlar-Carbon composite panels of $150 \times 100 \mathrm{~mm}^{2}$ was conducted by the authors. Using the design of experiments method and the Design Expert software tool, the data obtained in FEA environment is validated, through means of statistical distributions, by the experimental tests results.
\end{abstract}

Keywords: composite panels, impact test, FEA, validation

Composite structures have been widely used in the aerospace industry and, nowadays, the automotive manufacturers are determined to use these types of materials in the development process of distinct parts and / or assemblies [1-14]. These composite structures can fulfil the constantincrease in quantity and quality demanded by the clients of the automotive industry, even if the situation also requires changes in planning, design, finance, production and sales.

Throughout the years, intense research has been conducted regarding these composite structures that have offered insights regarding the behaviour of composite panels subjected to impact analysis. Examples of studies can be found in all technological domains such as: aerospace-Fiberglass [1-4] Carbon: [5-7], Kevlar-Carbon: [8-9] - and automotive -Fiberglass: [3,4,8] Carbon: [1011], Kevlar: [12], Kevlar-Carbon: [13-14]. These papers are all taking into consideration the complete mechanics of composite panels under impact loading [15]. In terms of numerical simulation, several researches have also been conducted [16-17]. Furthermore, the intense interest manifested by various industries - aerospace being the pioneer - in the composite materials generally and methods of testing such composite panels specifically have led to the standardization of the named methods [18-20].

The current research presents a validation study of composite panels made from different fibres - Fiberglass, Carbon and Kevlar-Carbon - with same layup distribution considering finite elementanalysis and experimental trials. The novelty of the present study is the validation method itself based on the design of experiments approach as presented hereafter.

Thus, the model is designed in the virtual environment and represents composite panels of $150 \times 100 \mathrm{~mm}^{2}$ consisting of the previously named fibres subjected to an impact energy of 30] in the form of one uniform distributed pressure load. The main advantage of this finite element assessment is the possible discovery of a weakness in a certain design before the part is actually manufactured.

Afterwards, the experimental trials are conducted to validate the results obtained from the finite element analysis. These trials are computed considering the design of experiments theory and Design Expert system [21] in which the main concern is to establish the validity, reliability and replicability of the proposed model. Furthermore, this concept also involves the delivery of an optimal structure given all constraints by selecting the conditions and outcomes under a certain plan.

\section{Experimental part}

The trials presented in this study consider the following data as shown in figure 1 :

- Panel length and width are $150 \mathrm{~mm}$ and $100 \mathrm{~mm}$, respectively;

- Configuration of the selected composite panels subject of this research is (0/90/45/-45/0/0/-45/45/90/0) with a maximum thickness depending on the material categories presented hereafter:

- Fiberglass MAT 300 with $6.0 \mathrm{~mm}$ panel thickness;

- Fiberglass ROW ING 300 with 4.0 mm panel thickness;

- Carbon 3K 285 with $5.00 \mathrm{~mm}$ panel thickness; and

- Kevlar-Carbon 215 with 5.00 mm panel thickness;

- Charpy flatwise impact with normal direction of blow;

- Impact energy of 30] - maximum energy of the experimental stand;

- Impact analysis is realized with an impactor having a spherical head of diameter $15 \mathrm{~mm}$ considering one experimental stand.

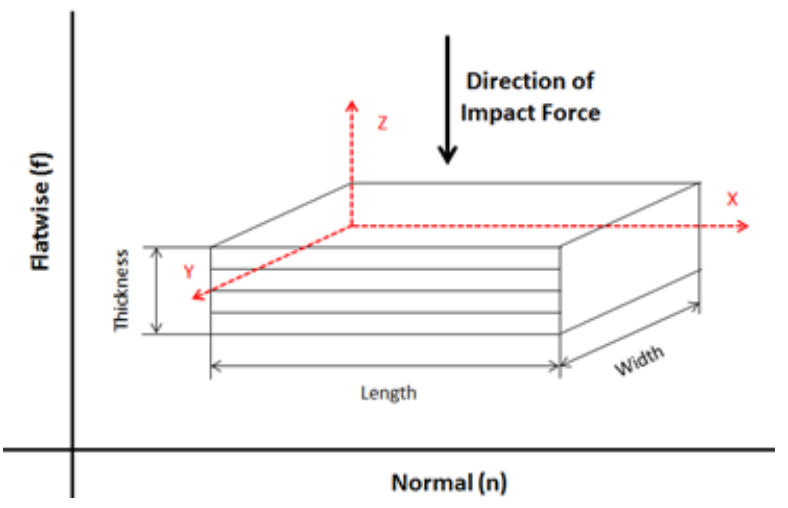

Fig. 1. Research method data

Note that the maximum thickness does not consider the thickness of the resin which is applied to glue the fibres together; this resin can expand or compress the sample in different areas.

The panels are loaded with a uniform distributed pressure in order to obtain results in the form of deformations and stresses which are used to determine mathematical models of the dependences between impact properties and composite panel structure. Various reasons, the most important being the increasing necessity of material saving at a global level, determines the usage of design of experiments method [22] in order to validate the previous obtained results before the manufacturing of

\footnotetext{
* email: emil.ca2651@yahoo.com
} 
any composite parts from the selected materials. Thus, the number of tests is determined, performed on an experimental stand and the results of the trials are set as input data for the next step of the w orkflow. The input data for the application Design Expert are the results of experiments performed on composite panels for each studied material category - in a total number of 10 samples - with previously named dimensions. These results are compared to the FEA ones in order to validate them. The application Design Expert returns individual results in the form of standard mean, standard deviation, standard ratio, trust degree of the given input data, different probability diagrams and residuals calculations and creates a statistical database for further use.

The complete workflow of the research is presented in figure 2 .

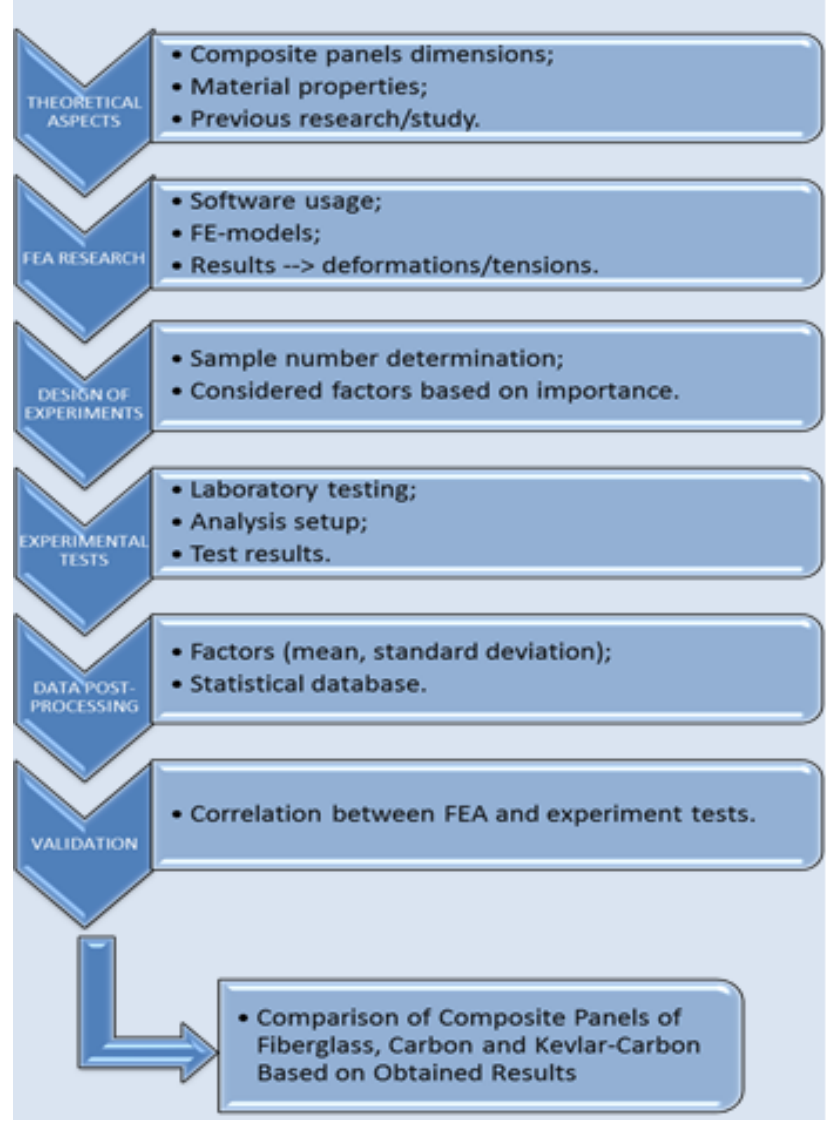

Fig.2. Research method workflow

Methods of assessment - finite element analysis

The finite element analysis at hand describes a local stress analysis of the created composite panel model itself. Finite element analysis is a numerical technique for assessing solutions although approximate depending on the limitations to different problems by means of differential equations. Finite element modelling takes into consideration all the modes utilized to assess a large number of simple elements equations over their respective subdomains, entitled finite elements, to obtain results of a more complex equation over a larger domain [23]. Nowadays, finite element analysis represents the key to all the manufacturing and development issues which companies in different domains of activity come across, issues such as new / improved methods of fabrication / post-processing and limitations of materials. In order to estimate the impact properties of composite panels made from selected materials - Fiberglass, Carbon and KevlarCarbon - a discrete finite element model is created by using the duo of applications available from the company MSC.Software: Patran [24] for pre- / post- processing of the model and Nastran [25] as the mathematical solver.

The performed finite element analysis has to take into consideration the following assumptions and / or requirements:

- Laminates of isotropic layers are the basis constituents of the composite panel;

- Material properties of these fibres are presented in table 1 ; ithas to be mentioned that these properties are required in order to model the panel in Patran application;

- Panels are stiffened to the device for testing; this situation is modelled by simulating boundary conditions in the FEA application - node constraints in all directions at the respective positions (translations and / or rotations about $X-, Y$ - and Z-axis);

- Specific loading is applied to the composite panel; the load is one distributed pressure at the centre of the panel depicting the equivalent of a drop-down tower test with an impact energy of 30] ;

- Impact test results in damage of the composite panel which is an equivalent of the deterioration of the constituent materials of the composite panel during manufacturing, assembly or actual usage process;

- Correctness of elementmodelling; in the finite element analysis of panels such as the ones being assessed, it is usually used the finite element type CQUAD4 an element that defines a membrane or plate subjected to bending and / or plane strains in an iso-parametric mode; this type of elements is coupled with the layer option of property definition from the pre-post processor of the finite element model;

- Avoidance of FATAL and ERROR messages during calculation with mathematical solver;

- Results visual validation: displacements and stress areas look natural;

- Reaction forces are equal to the applied forces.

The results of the finite element analysis are deformations and tensions of the researched composite panels. The complete model of the composite panel itself is presented in figure 3 . The selected analysis for this finite element model is Nastran's SOL 106 - the non-linear static solution where we can define the NLPARM option. With this parameter there are defined the strategies for the incremental and iterative solution processes of the mathematical solver. Basically, these processes are performed in the following manner: the maximum load is divided into increments of 10 percent each which are applied in an iterative mode. During the first increment, the requested output data is computed. Afterwards, another increment of 10 percent load is added to the first and the output data is calculated again taking into consideration the results from the previous loop. And so

\begin{tabular}{|c|c|c|c|c|c|c|}
\hline Property & \multicolumn{2}{|c|}{ Elastic Modulus } & Poisson's ratio & \multicolumn{3}{|c|}{ Shear Modulus } \\
\hline $\begin{array}{c}\text { Material Type } \\
{[-]}\end{array}$ & $\begin{array}{c}\mathrm{E}_{\mathrm{xx}} \\
{[\mathrm{MPa}]}\end{array}$ & $\begin{array}{c}\mathrm{E}_{\mathrm{yy}} \\
{[\mathrm{MPa}]}\end{array}$ & $\begin{array}{c}v \\
{[-]}\end{array}$ & $\begin{array}{c}\mathrm{G}_{\mathrm{xy}} \\
{[\mathrm{MPa}]}\end{array}$ & $\begin{array}{c}\mathrm{G}_{\mathrm{yz}} \\
{[\mathrm{MPa}]}\end{array}$ & $\begin{array}{c}\mathrm{G}_{\mathrm{zx}} \\
{[\mathrm{MPa}]}\end{array}$ \\
\hline Fiberglass & 20000 & 20000 & 0.20 & 3000 & 1 & 1 \\
\hline Carbon & 56000 & 56000 & 0.18 & 2850 & 1 & 1 \\
\hline Kevlar & 25900 & 25900 & 0.7 & 1 & 60 & 30 \\
\hline
\end{tabular}

Table 1

PROPERTIES OF MATERIALS IN FEA 

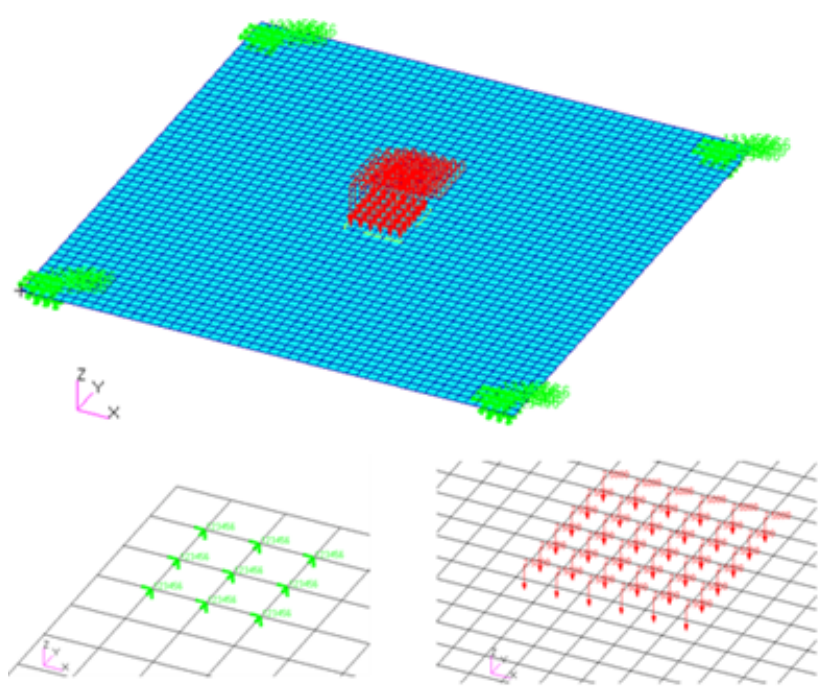

Fig. 3. Finite element model: a) overall finite element modelling; b) boundary conditions detail; c) specific loading detail.

on, until the model is fully loaded - 100 percent load - and all data are known.

\section{Methods of assessment - design of experiments}

Design of experiments is a tool used in a systematic way in order to examine different types of issues which appear in the research-development and manufacturing fields [26]. It is clear that a series of tests performed at random will give random results. Thus, the necessity to plan the trials in such a manner that the information output would be at its maximum emerges [27]. Such is the case of the present research. Considering the investigation is performed by following 4 factors (impact force, imprint length, imprint width and type of failure) - each of them with two levels (a maximum and a minimum for each factor) - the number of tests to be done is $2^{4}=16$ tests as shown in table 2.

Table 2

COMPLETE FACTORIAL PLAN

\begin{tabular}{|c|c|c|c|c|c|c|c|c|c|}
\hline \multicolumn{9}{|c|}{ Factors } & \multicolumn{5}{c|}{ Factors } \\
\hline Test & $\mathrm{X}_{1}$ & $\mathrm{X}_{2}$ & $\mathrm{X}_{3}$ & $\mathrm{X}_{4}$ & Test & $\mathrm{X}_{1}$ & $\mathrm{X}_{2}$ & $\mathrm{X}_{3}$ & $\mathrm{X}_{4}$ \\
\hline 1 & - & - & - & - & 9 & - & - & - & + \\
\hline 2 & + & - & - & - & 10 & + & - & - & + \\
\hline 3 & - & + & - & - & 11 & - & + & - & + \\
\hline 4 & + & + & - & - & 12 & + & + & - & + \\
\hline 5 & - & - & + & - & 13 & - & - & + & + \\
\hline 6 & + & - & + & - & 14 & + & - & + & + \\
\hline 7 & - & + & + & - & 15 & - & + & + & + \\
\hline 8 & + & + & + & - & 16 & + & + & + & + \\
\hline
\end{tabular}

where the following notations apply: $X_{1}$ - impact force; $X_{2}$ - imprint length; $X_{3}$ - imprint width; $X_{4}$ - type of failure; "-" - minimum value of factor; " +" - maximum value of factor.
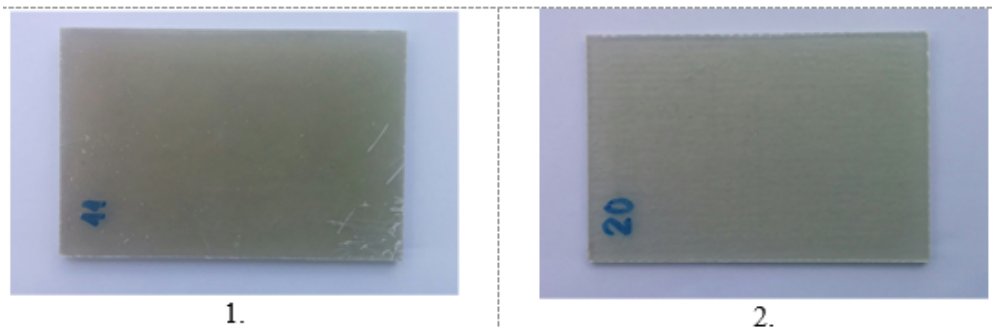

Fig. 4. Composite panels for experimental tests plan shown above comes to hand and a new factorial plan s proposed. This plan considers that, in an orthogonal matrix, e level of each factor is combined in an equal number with each level of the other factors [28]. As such, only $2^{3}=$ 8 trials are required for the validation of the finite element analysis. Considering that for the determination of any statistical data the highest and lowest values are ignored, the resulting number of trials is $10\left(2^{3}=8\right.$ trials from factorial plan +1 trial for highest value +1 trial for lowest value) . This number comes into agreement with [18-20] where it is stated that a set of 10 specimens shall be tested in order for the results to be validated.

\section{Methods of assessment - experimental tests}

As mentioned beforehand, a number of 10 composite panels for each material category involved in this study are tested for the confirmation of the research results. One sample of each composite panel is presented in figure 4.

All of these samples are cut to the testing dimensions from a bigger panel of $1000 \mathrm{~mm} \times 1000 \mathrm{~mm}$ which is covered with a peel-ply (removed during the actual testing). In order for the panels to be accepted for testing, a measurement is performed in the four corner of each sample to determine the mean thickness of each one. The mean thickness range of each category of composite panels should be as small as possible in order for the results to be viable as shown in table 3 and table 4. The properties of the materials for each category of composite samples have been presented during the finite element analysis description along with the stiffening mode on the testing machine itself.

Note that the Fiberglass MAT 300 samples have also been tested even if the mean thickness range was not acceptable. This was done for calibration and equipment functioning purposes.

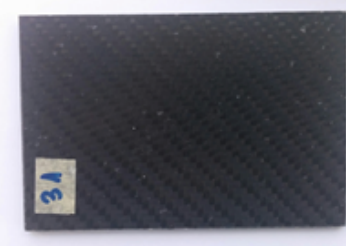

3. 


\begin{tabular}{|c|c|c|c|}
\hline Fiberglass Mat 300 & Fiberglass Rowing 300 & Carbon 3K 285 & Kevlar-Carbon 215 \\
\hline $\begin{array}{c}5.55<= \\
\mathrm{t}_{\text {mean }}<=6.88\end{array}$ & $\begin{array}{c}3.45<= \\
\mathrm{t}_{\text {mem }}<=3.80\end{array}$ & $\begin{array}{c}5.28<= \\
\mathrm{t}_{\text {mem }}<=5.88\end{array}$ & $\begin{array}{c}4.63<= \\
\mathrm{t}_{\text {mem }}<=5.20\end{array}$ \\
\hline $\begin{array}{c}\text { Not Acceptable } \\
\text { (bigger than } 1 \mathrm{~mm} \text { ) }\end{array}$ & $\begin{array}{c}\text { Acceptable } \\
\text { (smaller than } 1 \mathrm{~mm} \text { ) }\end{array}$ & $\begin{array}{c}\text { Acceptable } \\
\text { (smaller than } 1 \mathrm{~mm} \text { ) }\end{array}$ & $\begin{array}{c}\text { Acceptable } \\
\text { (smaller than } 1 \mathrm{~mm} \text { ) }\end{array}$ \\
\hline
\end{tabular}

Table 3

MEAN THICKNESS OF COMPOSITE SAMPLES

\begin{tabular}{|l|l|l|}
\hline \multicolumn{3}{|c|}{ Legend } \\
\hline \multirow{2}{*}{ Sample No. } & Thickness Comer 1 & Thickness Comer 3 \\
\cline { 2 - 3 } & Thickness Comer 2 & Thickness Comer 4 \\
\hline
\end{tabular}

Table 4

THICKNESS MEASUREMENTS OF COMPOSITE SAMPLES

\begin{tabular}{|c|c|c|c|c|c|c|c|c|c|c|c|}
\hline \multicolumn{3}{|c|}{ Fiberglass Mat 300} & \multicolumn{3}{|c|}{ Fiberglass Rowing 300} & \multicolumn{3}{|c|}{ Carbon 3K 285 } & \multicolumn{3}{|c|}{ Kevlar-Carbon 215} \\
\hline \multirow{2}{*}{1} & 6.0 & 6.0 & \multirow{2}{*}{12} & 3.4 & 3.5 & \multirow{2}{*}{23} & 5.4 & 6.3 & \multirow{2}{*}{33} & 4.5 & 4.6 \\
\hline & 6.0 & 5.9 & & 3.5 & 3.4 & & 5.2 & 5.7 & & 4.6 & 4.8 \\
\hline \multirow{2}{*}{2} & 7.2 & 7.7 & \multirow{2}{*}{13} & 3.7 & 3.6 & \multirow{2}{*}{24} & 5.3 & 5.1 & \multirow{2}{*}{34} & 5.0 & 4.7 \\
\hline & 6.1 & 6.5 & & 3.6 & 3.6 & & 5.4 & 5.4 & & 4.9 & 4.7 \\
\hline \multirow{2}{*}{3} & 6.2 & 5.9 & \multirow{2}{*}{14} & 3.6 & 3.6 & \multirow{2}{*}{25} & 5.3 & 5.3 & \multirow{2}{*}{35} & 4.7 & 5.0 \\
\hline & 6.4 & 6.7 & & 3.4 & 3.4 & & 5.5 & 5.2 & & 5.2 & 5.0 \\
\hline \multirow{2}{*}{4} & 6.4 & 6.8 & \multirow{2}{*}{15} & 3.6 & 3.5 & \multirow{2}{*}{26} & 5.4 & 5.3 & \multirow{2}{*}{36} & 4.6 & 4.8 \\
\hline & 6.3 & 6.0 & & 3.6 & 3.6 & & 5.3 & 5.3 & & 4.8 & 5.0 \\
\hline \multirow{2}{*}{5} & 5.8 & 5.6 & \multirow{2}{*}{16} & 3.6 & 3.6 & \multirow{2}{*}{27} & 5.4 & 5.5 & \multirow{2}{*}{37} & 5.3 & 5.3 \\
\hline & 6.2 & 5.7 & & 3.6 & 3.5 & & 5.8 & 5.7 & & 5.3 & 4.9 \\
\hline \multirow{2}{*}{6} & 7.3 & 6.6 & \multirow{2}{*}{17} & 3.8 & 3.5 & \multirow{2}{*}{28} & 5.3 & 5.6 & \multirow{2}{*}{38} & 4.6 & 5.1 \\
\hline & 6.3 & 6.0 & & 3.6 & 3.6 & & 5.2 & 5.8 & & 4.6 & 5.3 \\
\hline \multirow{2}{*}{7} & 6.0 & 6.2 & \multirow{2}{*}{18} & 3.8 & 3.8 & \multirow{2}{*}{29} & 5.8 & 5.6 & \multirow{2}{*}{39} & 5.2 & 5.1 \\
\hline & 6.3 & 6.0 & & 4.0 & 3.6 & & 5.5 & 5.3 & & 4.9 & 5.1 \\
\hline 8 & 6.0 & 6.0 & 10 & 3.7 & 3.6 & 30 & 5.5 & 6.0 & 40 & 5.0 & 5.0 \\
\hline $0^{\circ}$ & 6.0 & 5.2 & 19 & 3.4 & 3.6 & 50 & 5.8 & 6.2 & 40 & 5.0 & 5.0 \\
\hline 0 & 5.8 & 5.9 & 20 & 3.6 & 3.5 & 31 & 5.1 & 6.0 & $A 1$ & 4.8 & 5.0 \\
\hline 7 & 6.0 & 6.2 & 20 & 3.6 & 3.6 & 01 & 4.8 & 5.2 & 71 & 4.8 & 5.2 \\
\hline 10 & 5.5 & 5.1 & 21 & 3.4 & 3.5 & 32 & 6.2 & 5.8 & 42 & 5.1 & 5.1 \\
\hline 10 & 6.0 & 5.6 & 21 & 3.7 & 3.6 & 32 & 5.4 & 5.3 & +2 & 4.9 & 4.9 \\
\hline 11 & 6.6 & 6.7 & 27 & 3.5 & 3.7 & & & & & 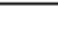 & \\
\hline 11 & 5.9 & 5.9 & 22 & 3.5 & 3.5 & & & & & - & \\
\hline
\end{tabular}

The equipment used for the experimental testing is depicted in figure 5. It is composed of a modified Charpy pendulum for strength tests. An impactor with a spherical head of diameter $15 \mathrm{~mm}$ is also added to the pendulum, thus generating one assembly which impacts the

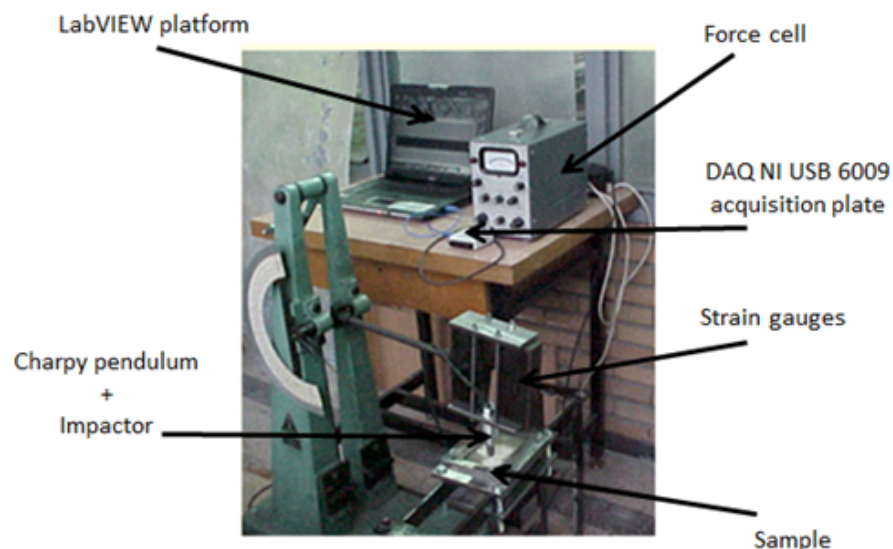

Fig. 5. Experimental stand used for testing

composite panel sample fixed with screws and plates. This assembly has mounted force cells with resistive strain gauges in order to transmit the electrical signals given by the impactor to one DAQ NI USB 6009 acquisition plate. With a rate of acquisition of 2500 or 5000 signals per second and editing in a LabVIEW platform installed on a computer, the history curves of the impact force are obtained on a time frame of 5 - 10 milliseconds.

\section{Results and discussions}

Finite element analysis

The calculation is performed with the mathematical solver Nastran (entitled run) and the results are given into 2 files: one file with extension*.xdb which contains output data such as displacements, tensions, constraint forces, a.s.o., and another file with extension *.f06 which contains data from the actual run itself regarding finite element modelling, application of forces and boundary conditions and also the maximum displacements in numerical format - presented in the table 5.

It can be seen that the translations on $X$ - and $Y$-axis are practically null and the one on Z-axis represents the only concern. The rotations around all axes are negligible. Clearly, the composite panels made out of fiberglass will break easily - maximum deformation in this case is 7.67 $\mathrm{mm}$. The Carbon and Kevlar-Carbon panels are much more resistant with values of $4.95 \mathrm{~mm}$ and $3.36 \mathrm{~mm}$ respectively for maximum deformation. Another factor to take into consideration is the amount of impact force which is absorbed by the composite panel itself. This is computed as the difference between applied load (also entitled overall load) and the load shown at the boundary conditions (single point constraints load) and the results are shown in table 


\begin{tabular}{|c|c|c|c|c|c|c|c|}
\hline \multicolumn{7}{|c|}{ MAXIMUM DISPLACEMENTS } & \multirow{5}{*}{$\begin{array}{c}\text { Table } 5 \\
\text { FINITE } \\
\text { ELEMENT } \\
\text { MODEL } \\
\text { RESULTS - } \\
\text { DEFORMATIONS }\end{array}$} \\
\hline $\begin{array}{c}\text { Material } \\
\text { Type } \\
{[-]}\end{array}$ & $\begin{array}{c}\mathrm{T} 1 \\
{[\mathrm{~mm}]}\end{array}$ & $\begin{array}{c}\mathrm{T} 2 \\
{[\mathrm{~mm}]}\end{array}$ & $\begin{array}{c}\mathrm{T} 3 \\
{[\mathrm{~mm}]}\end{array}$ & $\begin{array}{c}\mathrm{R} 1 \\
{[\mathrm{~mm}]}\end{array}$ & $\begin{array}{c}\mathrm{R} 2 \\
{[\mathrm{~mm}]}\end{array}$ & $\begin{array}{c}\mathrm{R} 3 \\
{[\mathrm{~mm}]}\end{array}$ & \\
\hline Fiberglass & $\begin{array}{c}1.5771991 \mathrm{E} \\
-01\end{array}$ & $\begin{array}{c}1.5771991 \mathrm{E} \\
-01\end{array}$ & $\begin{array}{c}7.6713772 \mathrm{E} \\
+00\end{array}$ & $\begin{array}{c}2.0307607 \mathrm{E} \\
-03\end{array}$ & $\begin{array}{c}2.0307607 \mathrm{E} \\
-03\end{array}$ & $\begin{array}{c}6.5322160 \mathrm{E} \\
-03\end{array}$ & \\
\hline Carbon & $\begin{array}{c}6.9552869 \mathrm{E} \\
-02\end{array}$ & $\begin{array}{c}6.9552869 \mathrm{E} \\
-02\end{array}$ & $\begin{array}{c}4.9511933 \mathrm{E} \\
+00\end{array}$ & $\begin{array}{c}5.2510167 \mathrm{E} \\
-04\end{array}$ & $\begin{array}{c}5.2510167 \mathrm{E} \\
-04\end{array}$ & $\begin{array}{c}2.7448039 \mathrm{E} \\
-03\end{array}$ & \\
\hline $\begin{array}{l}\text { Kevlar- } \\
\text { Carbon }\end{array}$ & $\begin{array}{c}1.6741989 \mathrm{E} \\
-02 \\
\end{array}$ & $\begin{array}{c}1.6741989 \mathrm{E} \\
-02 \\
\end{array}$ & $\begin{array}{c}3.3874319 \mathrm{E} \\
+00 \\
\end{array}$ & $\begin{array}{c}6.1562686 \mathrm{E} \\
-04 \\
\end{array}$ & $\begin{array}{c}6.1562686 \mathrm{E} \\
-04 \\
\end{array}$ & $\begin{array}{c}1.2402001 \mathrm{E} \\
-03 \\
\end{array}$ & \\
\hline
\end{tabular}
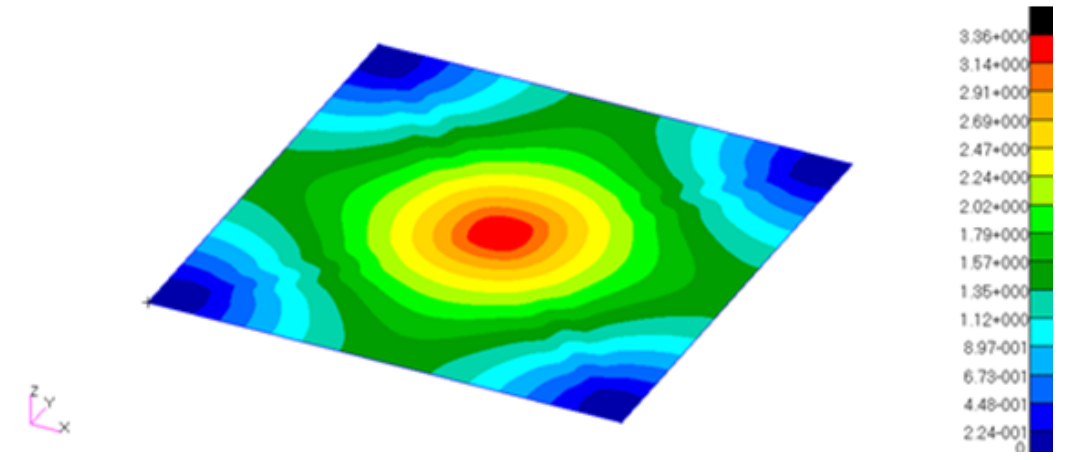

Fig. 6. Finite element model - displacement of Kevlar-Carbon composite panel

\begin{tabular}{|c|c|c|c|}
\hline Material Category & Overall Load & SPC Load & Impact Force \\
\hline$[-]$ & {$[\mathrm{N}]$} & {$[\mathrm{N}]$} & {$[\mathrm{N}]$} \\
\hline Fiberglass & 4500 & 0 & 4500 \\
\hline Carbon & 4500 & 300 & 4200 \\
\hline Kevlar-Carbon & 4500 & 2500 & 2000 \\
\hline
\end{tabular}

Table 6

AMOUNT OF ABSORBED LOAD
6. One example of deformation for the Kevlar-Carbon composite panel can be seen in figure 6 .

Experimental tests outcome

In this section, the results from experiments are presented. The results are collected by means of LabVIEW software for 10 samples of each composite material category considering that the total impact energy is 30] for all impacts (which includes also gravitational acceleration). The application presents a waveform chart of time (seconds) vs. amplitude (Volts). Using a calibration curve between the two variables, the impact force is determined. As an example, the results from sample number 3 are presented in figure 7. The amplitude obtained by the equipment helps to obtain the impact force which is plotted to determine its maximum at the time of impact.

The complete results are presented in figure 8 , table 7 and table 8 (the maximum impact force, imprint length, imprint width and type of failure for each sample of each material category). The green dash lines represent the trust degree interval considering the introduced values for the impact force. The difference in sample numbers between table 4 and table 7 is due to the sample handling during actual testing (some samples have been shattered by accident) and the type of failure has only two possible values: 0 for samples which did not present full break and 1 for sample of opposite type.

\section{Data processing}

The analysis of the data obtained by experimental tests is performed in the application Design Expert in order to return the following aspects of each studied material category: standard mean, standard deviation, standard error and trust degree ( 95 percent interval). The application Design Expert is a dedicated one and provides powerful statistical tools such as, Design Expert (2016):

- Screening designs used to identify vital factors that affect the users process;
- Factorial studies for the discovery of right combinations between factors of different categories;

- Statistical details for process improvement;

- Function optimization based on multiple registered responses.

Hence, considering all results from the Design Expert calculations for impact force, imprint length, imprint width and type of failure are available, a comparison to the results of the finite element analysis is performed and a check is given for each calculation in the terms of match and no match. This comparison is presented in table 9 . In every

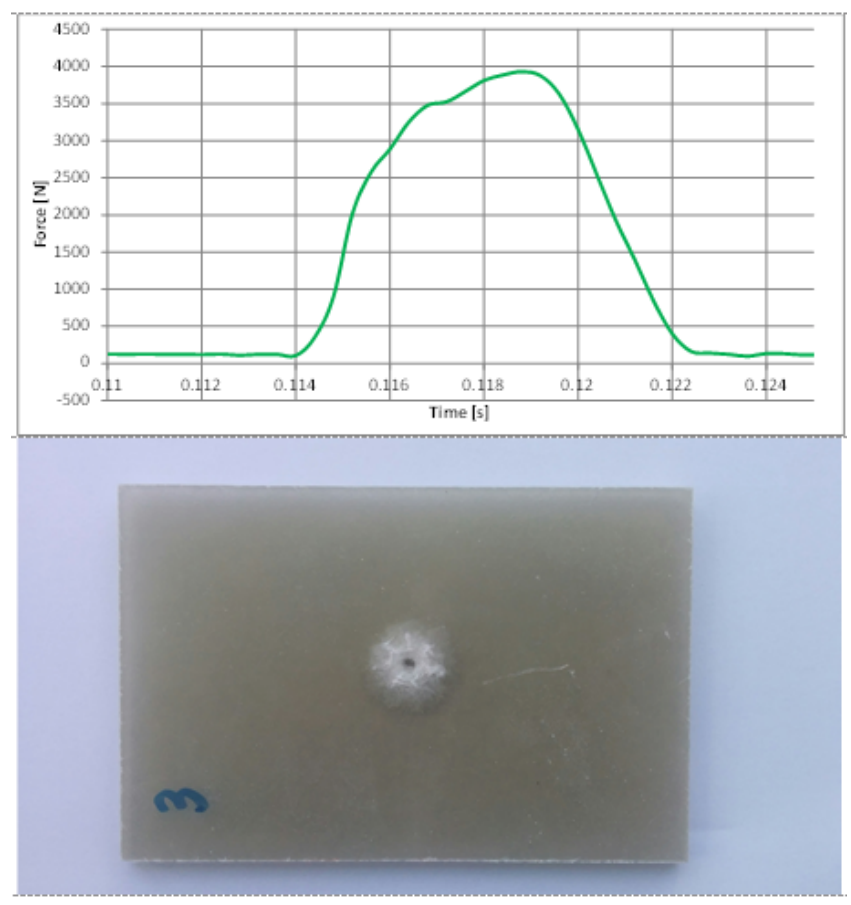

Fig. 7. Sample 3 results - LabVIEW curve data and tested sample 


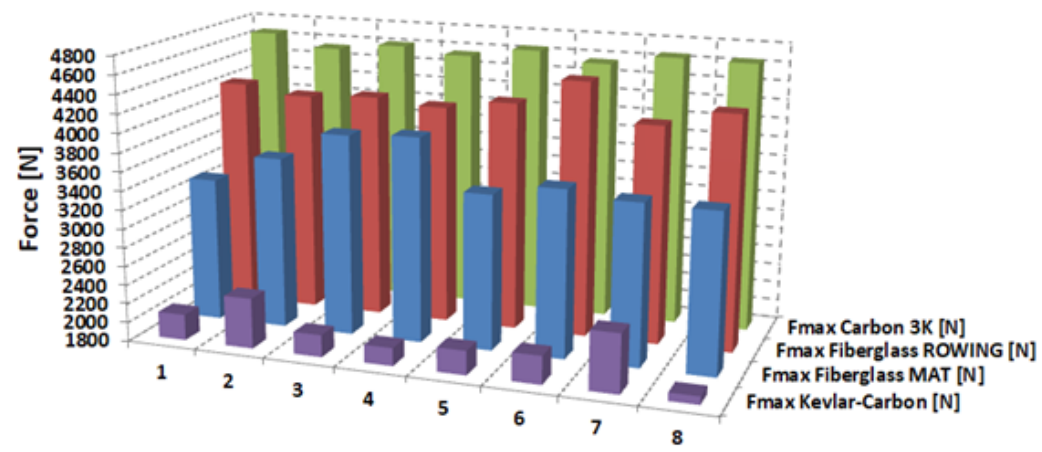

Sample Number [-]

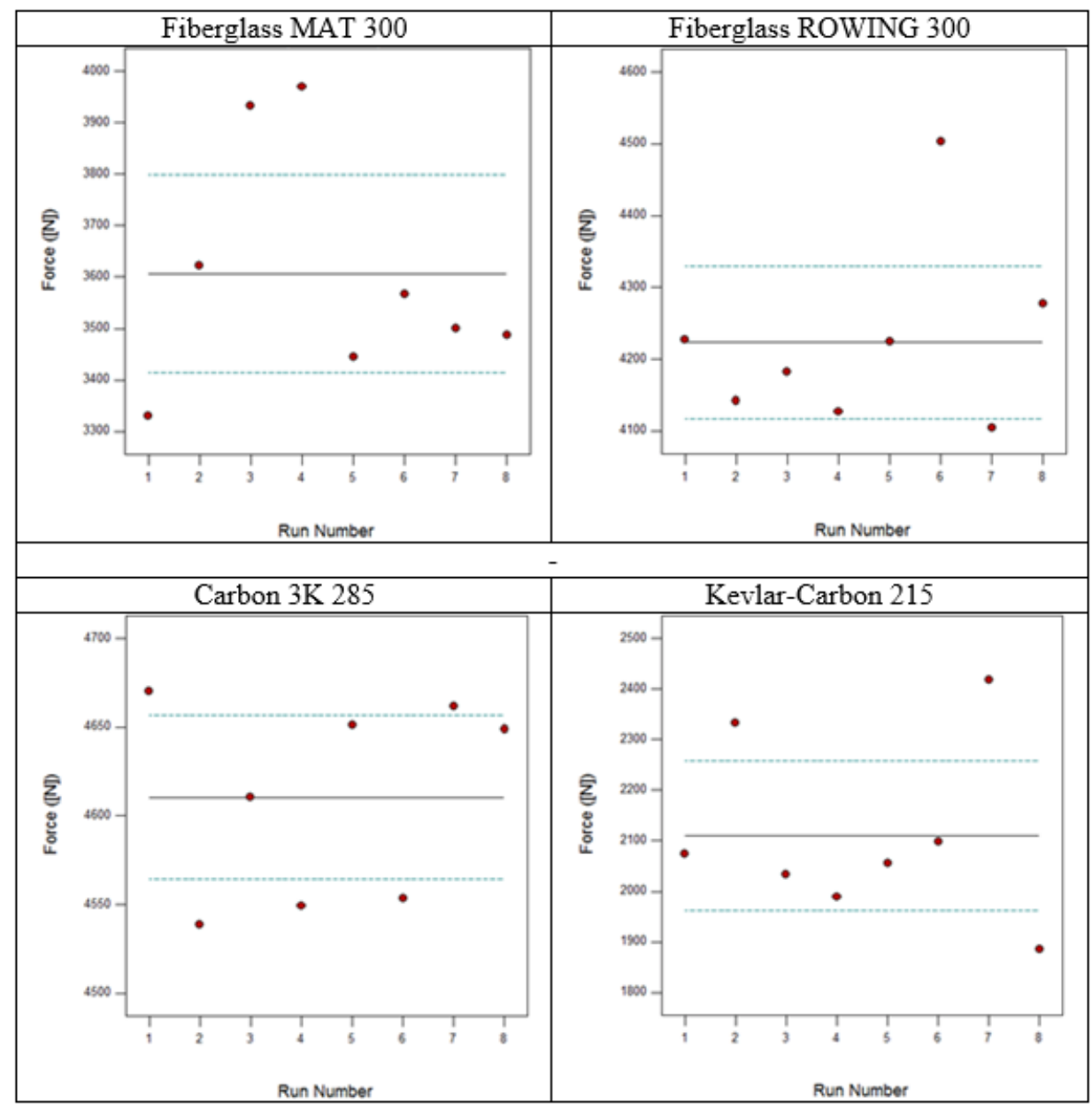

Table 7

DESIGN EXPERT CALCULATIONS FOR TRUST DEGREE OF THE IMPACT FORCE

Table 8

COMPARISON OF RESULTS AND CONCLUSION

\begin{tabular}{|c|c|c|c|c|c|c|}
\hline $\begin{array}{l}\text { Material } \\
\text { Category }\end{array}$ & $\begin{array}{c}\text { Design Expert } \\
\text { Data }\end{array}$ & $\begin{array}{l}\text { Impact } \\
\text { Force }\end{array}$ & $\begin{array}{l}\text { Imprint } \\
\text { Length }\end{array}$ & $\begin{array}{l}\text { Imprint } \\
\text { Width }\end{array}$ & $\begin{array}{l}\text { Type of } \\
\text { Failure }\end{array}$ & $\begin{array}{c}\text { FEM } \\
\text { Results }\end{array}$ \\
\hline$[-]$ & {$[-]$} & [N] & [mm] & {$[\mathrm{mm}]$} & {$[-]$} & {$[-]$} \\
\hline \multirow{3}{*}{$\begin{array}{l}\text { Fiberglass } \\
\text { MAT } 300\end{array}$} & Std mean & 3606.46 & 25.13 & 23.00 & 1.00 & \multirow{3}{*}{ match } \\
\hline & Std. deviation & 229.54 & 4.36 & 1.85 & 0.00 & \\
\hline & Std. error & 81.15 & 1.54 & 0.65 & 0.00 & \\
\hline \multirow{3}{*}{$\begin{array}{c}\text { Fiberglass } \\
\text { ROWING } \\
300\end{array}$} & Std. mean & 4223.25 & 37.75 & 24.75 & 1.00 & \multirow{3}{*}{ match } \\
\hline & Std. deviation & 126.92 & 2.49 & 1.39 & 0.00 & \\
\hline & Std. error & 44.87 & 0.88 & 0.49 & 0.00 & \\
\hline \multirow{3}{*}{$\begin{array}{c}\text { Carbon } 3 \mathrm{~K} \\
285\end{array}$} & Std. mean & 4610.40 & 25.50 & 16.63 & 0.00 & \multirow{3}{*}{ match } \\
\hline & Std. deviation & 55.37 & 3.07 & 2.45 & 0.00 & \\
\hline & Std. error & 19.58 & 1.09 & 0.86 & 0.00 & \\
\hline \multirow{3}{*}{$\begin{array}{c}\text { Kevlar- } \\
\text { Carbon } 215\end{array}$} & Std. mean & 2110.75 & 24.63 & 17.50 & 0.38 & \multirow{3}{*}{ match } \\
\hline & Std. deviation & 177.14 & 3.16 & 2.45 & 0.52 & \\
\hline & Std. error & 62.63 & 1.12 & 0.87 & 0.18 & \\
\hline
\end{tabular}




\begin{tabular}{|c|c|c|c|c|c|c|c|c|c|}
\hline \multicolumn{5}{|c|}{ Fiberglass Mat 300} & \multicolumn{5}{|c|}{ Fiberglass Rowing 300} \\
\hline $\begin{array}{c}\text { Sample } \\
\text { No. }\end{array}$ & $\begin{array}{l}\text { Impact } \\
\text { Force }\end{array}$ & $\begin{array}{l}\text { Imprint } \\
\text { Length }\end{array}$ & $\begin{array}{l}\text { Imprint } \\
\text { Width }\end{array}$ & $\begin{array}{l}\text { Type of } \\
\text { Failure }\end{array}$ & $\begin{array}{c}\text { Sample } \\
\text { No. }\end{array}$ & $\begin{array}{l}\text { Impact } \\
\text { Force }\end{array}$ & $\begin{array}{l}\text { Imprint } \\
\text { Length }\end{array}$ & $\begin{array}{l}\text { Imprint } \\
\text { Width }\end{array}$ & $\begin{array}{l}\text { Type of } \\
\text { Failure }\end{array}$ \\
\hline$[-]$ & [N] & [mm] & {$[\mathrm{mm}]$} & {$[-]$} & {$[-]$} & {$[\mathrm{N}]$} & [mm] & [mm] & {$[-]$} \\
\hline 1 & 3330 & 23 & 25 & 1 & 12 & 4227 & 36 & 22 & 1 \\
\hline 2 & 3622 & 30 & 25 & 1 & 13 & 4142 & 41 & 24 & 1 \\
\hline 3 & 3932 & 20 & 22 & 1 & 14 & 4182 & 40 & 26 & 1 \\
\hline 4 & 3970 & 24 & 20 & 1 & 15 & 4127 & 37 & 24 & 1 \\
\hline 5 & 3444 & 28 & 22 & 1 & 16 & 4225 & 39 & 26 & 1 \\
\hline 6 & 3567 & 23 & 22 & 1 & 17 & 4503 & 38 & 25 & 1 \\
\hline 7 & 3499 & 32 & 25 & 1 & 18 & 4104 & 33 & 26 & 1 \\
\hline 8 & 3487 & 21 & 23 & 1 & 19 & 4278 & 38 & 25 & 1 \\
\hline
\end{tabular}

Table 9 EXPERIMENTAL TESTS RESULTS

\begin{tabular}{|c|c|c|c|c|c|c|c|c|c|}
\hline \multicolumn{5}{|c|}{ Carbon 3K 285 } & \multicolumn{5}{|c|}{ Kevlar-Carbon 215 } \\
\hline $\begin{array}{c}\text { Sample } \\
\text { No. }\end{array}$ & $\begin{array}{c}\text { Impact } \\
\text { Force }\end{array}$ & $\begin{array}{c}\text { Imprint } \\
\text { Length }\end{array}$ & $\begin{array}{c}\text { Imprint } \\
\text { Width }\end{array}$ & $\begin{array}{c}\text { Type of } \\
\text { Failure }\end{array}$ & $\begin{array}{c}\text { Sample } \\
\text { No. }\end{array}$ & $\begin{array}{c}\text { Impact } \\
\text { Force }\end{array}$ & $\begin{array}{c}\text { Imprint } \\
\text { Length }\end{array}$ & $\begin{array}{c}\text { Imprint } \\
\text { Width }\end{array}$ & $\begin{array}{c}\text { Type of } \\
\text { Failure }\end{array}$ \\
\hline$[-]$ & {$[\mathrm{N}]$} & {$[\mathrm{mm}]$} & {$[\mathrm{mm}]$} & {$[-]$} & {$[-]$} & {$[\mathrm{N}]$} & {$[\mathrm{mm}]$} & {$[\mathrm{mm}]$} & {$[-]$} \\
\hline 23 & 4670 & 24 & 14 & 0 & 33 & 2074 & 25 & 18 & 1 \\
\hline 24 & 4539 & 23 & 13 & 0 & 34 & 2333 & 20 & 15 & 0 \\
\hline 25 & 4611 & 27 & 18 & 0 & 35 & 2034 & 26 & 15 & 0 \\
\hline 26 & 4549 & 29 & 17 & 0 & 36 & 1989 & 20 & 16 & 0 \\
\hline 27 & 4651 & 28 & 21 & 0 & 37 & 2055 & 24 & 17 & 0 \\
\hline 28 & 4553 & 28 & 17 & 0 & 38 & 2097 & 28 & 20 & 0 \\
\hline 29 & 4662 & 25 & 17 & 0 & 39 & 2418 & 28 & 22 & 1 \\
\hline 30 & 4649 & 20 & 16 & 0 & 40 & 1885 & 26 & 17 & 1 \\
\hline
\end{tabular}

cell, the numbers represent the standard mean, the standard deviation and the standard error.

\section{Conclusions}

This paper presented a method of validation for the finite element analysis of Fiberglass, Carbon and Kevlar-Carbon composite panels by means of design of experiments and experimental tests in order to have comparative results and to prove the advantages of the combination of these three approaches for the manufacturing of parts used in the aerospace and / or automotive industry. For example, due to the high impact resistance, the Kevlar-Carbon composite panels should be used in the development of left / right fenders and doors of different vehicles such as automobiles and motorcycles or hulls and carcases of yachts.

The data obtained from the finite elementanalysis allows the comparison with the results of the experimental trials and calculated with design of experiments factorial plans. The method will be used in future work for the validation of finite element analysis of automotive parts such as the front left wing or different fenders. Also, the mathematical model of the factorial plan will be involved in the development process of software that has the scope of parameterized generation of such automotive parts.

Using this method of validation ensures that the composite panels have properly performance and structural reliability and are manufactured according to the specifications and requirements of the industry.

Acknowledgement: This paper is supported by the Sectoral Operational Programme Human Resources Development (SOP HRD), ID134378 financed from the European Social Fund and by the Romanian Government. The authors would like to thank the company S.C. Compozite S.R.L for all the support regarding the manufacturing of composite samples.

\section{References}

1. MALHOTRA, A., Impact Damage to Composite Laminates: Effect of Impact Location, Applied Composite Materials, 21, 2014, p.165.

2. BEJ, A., BORDEASU, I., MILOS, T., BADARAU, R., Considerations Concerning the Mechanical Strength of Wind Turbine Blades made of
Fiberglass Reinforced Polyester, MAT. PLAST., Volume: 49, Issue: 3, SEP 2012, pp. 212-218

3.IONESCU, N., GHIONEA, I., TONOIU, S., CATANA, M., Systemic Approach of Ultrasonically Assisted Cutting of Glass Fiber Reinforced Polymeric Materials, Mat. Plast., 52, no. 3, 2015, p.351

4.MARIES, G.R.E, Processing Temperatures Influence of Three Types of Polyamide 6.6 Reinforced with Different Percentages of Fiber Glass on Some Mechanical Properties, Mat. Plast., 52, no. 1, 2015, p.32

5. GUSTIN, J., Low-velocity Impact of Sandwich Composite Plates, Experimental mechanics, 44, 2004, p. 574.

6. JOHNSON, A. F., Design of Composite Wing Access Cover Under Impact Loads, Applied Composite Materials, 7, 2000, p. 219.4.

7. SANGA, R. P. L., Finite Element Simulation of Low Velocity Impact Damage on an Aeronautical Carbon Composite Structure, Applied Composite Materials, 23, p. 1195.

8. KUMAR, N. J ., Investigations on Buckling Behaviour of Laminated Curved Composite Stiffened Panels, Applied Composite Materials, Vol. 21, 2014, p. 359.

9. KIM, H., DEFRANCISCI, G. K., CHEN, Z. M., Ground vehicle blunt impact damage formation to composite aircraft structures, Advanced Composite Materials, 23, 2014, p. 53

10. BUNEA, M., BOSOANCA, R., ENI C., CRISTACHE, N., STEFANESCU, V., The Impact Characteristics of Fabric Reinforced Hybrid Composites, Mat. Plast., 54, 2017, p. 286.

11. DAVIES, G. A. O., Impact Damage Prediction in Carbon Composite Structures, International J ournal of Impact Engineering, 16, 1994, p. 149.

12. REIS, P. N. B., Impact Response of Kevlar Composites with Filled Epoxy Matrix, Composite Structures, 94, 2012, p. 3520.

13. MAHINFALAH, M., Low Velocity Impact of Combination Kevlar/ Carbon Fibre Sandwich Composites, Composite Structures, 9, 2005, p. 396

14. KAMALDEEN, Y., MOHAMMAD, M., AMIN, S K., Low Velocity Impact of Carbon/Zylon and Carbon/Kevlar Composite Laminates, ASME 2005 International Mechanical Engineering Congress and Exposition Materials, 2005, p. 115.

15.J ONES, R. M., (1998), Mechanics of Composite Materials, Taylor and Francis, 1998.

16. NAIR, R. P., RAO, C. L., Numerical Simulation of Ballistic Impact on Particulate Composite Target using Discrete Element Method: 1-D and 2-D Models, International Journal for Computational Methods In Engineering Science and Mechanics, 15, 2014, p. 9. 
17. ZHANG, X., LIU, T., HE, N., JIA, G., Investigation of two finite element modelling approaches for ballistic impact response of composite laminates, International Journal of Crashworthiness, 22, 2017, p. 377.

18. *** ASTM D7136 / D7136M-15, Standard Test Method for Measuring the Damage Resistance of a Fiber-Reinforced Polymer Matrix Composite to a Drop-Weight Impact Event, ASTM International, West Conshohocken, PA, 2015

19. *** Plastics Determination of Charpy impact properties Part 1: Non-instrumented impact test, DIN EN ISO 179:1, 2000.

20. ***, (2001), Plastics Determination of Charpy impact properties Part 2: Instrumented impact test, DIN EN ISO 179:2.

21. Design Expert, http://www.statease.com/dx10.html, accessed on 12 May 2016.

22.ERIKSSON, L., (2008), Design of Experiments: Principles and Applications, MKS Umetrics AB, 2008.
23. ZIENKIEWICZ, O. C., TAYLOR, R. L., ZHU, J .Z., The Finite Element Method: Its Basis and Fundamentals, Elsevier, 2013.

24. *** Patran 2010 Quick Reference Guide Linear Static Analysis Users Guide, 2010.

25. *** Nastran 2010 Quick Reference Guide Linear Static Analysis User's Guide, 2010.

26. VASILE, G., FETECAU, C., AMARANDEI, D., SERBAN, A., Experimental Research on the Milling Process of Some Composite Materials, Mat. Plast., 53, no.1, 2016, p.157.

27. ELDIN, A. B., General Introduction to Design of Experiments, Intech, 2011.

28. ROY R, K., Basic Design of Experiments (Taguchi Approach), USA, 2001.

Manuscript received: 12.07 .2017 